\title{
RISK MANAGEMENT TECHNIQUES AND INSURANCE BUYING BEHAVIOUR: EVIDENCE FROM SMALL AND MEDIUM-SIZED ENTERPRISES IN LAGOS, NIGERIA
}

\section{DOI: 10.36108/ljerhrm/2202.03.0181}

\author{
ALAKA, Sanusi Nureni \\ Department of Business Administration, Faculty of Management Science, Lagos State University, \\ Lagos, Nigeria \\ nureni.alaka@lasu.edu.ng
}

AJEMUNIGBOHUN, Sunday Stephen

Department of Insurance, Faculty of Management Science, Lagos State University, Lagos, Nigeria sunday.ajemunigbohun@lasu.edu.ng

and

BALOGUN, Mustapha Tosin

Department of Marketing, Faculty of Management Sciences, Lagos State University, Lagos, Nigeria mustapha.balogun@lasu.edu.ng

\begin{abstract}
Risk management techniques are important metrics in safeguarding the lives and property of mankind. They influence the behavioural attitude of people to perceive the image of insurance as an intangible, inseparable, variable, and transferable product. Therefore, this study aimed at assessing the effects of risk management techniques on insurance buying behaviour, with specific reference to the perceptions of selected SMEs in Lagos, Nigeria. The study adopted a cross- sectional survey research design. The study populationconsisted of the total number of registered SMEs recorded in Lagos State at 11,666.Thus, a single-stage cluster sampling technique was employed in the questionnaire distribution and data collection processes. Two hundred and forty-three (243) respondents were used in the study. The statistical technique employed was simple regression. This study confirms the importance of risk management techniques in the behavioural evaluation of insurance purchases in Lagos, Nigeria. It is recommended that insurance providers in Nigeria should attempt to tailor insurance products in a lovable and affordable manner to SMEs' operators/owners in a bid to improve on their behavioural risk attitudes. More so, interest should be placed on impressive risk management communication and ideal risk financing techniques among SMEs' owners/operators.
\end{abstract}

Keywords: Risk identification techniques, risk assessment techniques, risk control techniques, insurance buying behaviour, SMEs

\section{Introduction}

Small and medium enterprises (SMEs) are being acknowledged as moving train that spur the necessary economic growth and development of every nation and the world (Ajemunigbohun, Isimoya, \&Elegunde, 2020; Dayour, Adongo, \&Kimbu, 2020; Ledwin\& Watson, 2019). Observations from previous researches (such as Ayyagari, Demirguc-Kunt, \& Maksimovic, 2011; Chodokufa, 2016; Ruchkina, Melnichuk, Frumina, \& Mentel, 2017) agreed to the fact that not less than 95 percent of businesses were SMEs which are responsible for 60 percent private sector job 
chances. They iterated that the contributory proportion of SMEs in terms of businesses and job chances within African continent to stand nearly around 90 percent and 50 percent respectively. These opportunities can be widely annexed if the numerous risks accompanying the various businesses are well managed.

Risk is ubiquitous, and it permeates every facet of human endeavor. It is an endemic force in the quest for human and business survival (Adeyele\&Osemene, 2018; Al Qubtan, Gan, Abd. Hadi, Abdul Jalil \&Rambeli, 2021; Zoghi, 2017). According to Ibiwoye, Mojekwu, and Dansu (2020), major factors setting behind SMEs' survivals seen embedded in the numerous risks impinging their growth and performance in both economic and social space. Ajemunigbohun and Adeoye (2018) earlier suggested the need for appropriate risk management techniques, among categories of businesses at both small and medium levels, as this is lacking at either the federal, or the state, or the local government level. Earlier study of Mensah (2004) stated institutional and legal instruments that ought to bolster risk management among SMEs operators as lacking. Membula (2002) as cited in Ajemunigbohun and Adeoye (2018) aligned the incapacities of MSEs' operators to inadequate risk management education and knowledge.

However, poor risk identification, assessment and control techniques are major gaps in the desires of SMEs' operators/owners to get attracted to insurance, as a formidable financial instrument. Studies (such as Ekwere, 2016; Jenya \&Sandada, 2017; Grondys, Slusarczyk, Hussain, \&Androniceanu, 2021; Kehinde, Opeyemi, Benjamin, Adebayo, \& Abel, 2017; Lima \&Verbano, 2019) adjudged that due to low financial capacity and inadequate risk management expertise, SMEs' operators have perceived risk identification as a cost incurring element to their businesses rather than a task which is undertaken to safeguard their business goals and objectives. Risk management is, by and large, something that does not require instantaneous attentiveness until some incidences occur (Moore, Pretty, Palich, \& Longenecker, 2008 as cited in Chodokufa\&Chiliya, 2014). Studies (such as Chodokufa, 2016; Chodokufa\&Chiliya, 2014; Dayour et al., 2020; Chatterjee \&Wehrhah, 2017) had informed that prudent business owners are expected to take time to identify with the numerous types of risks encountered in their businesses and thus navigate means to respond and mitigate either its effects (impact) or size (severity). This, therefore, necessitate the need to carry out the study on the relationship between risk management techniques and insurance buying behaviour among SMEs in Lagos, Nigeria.

\section{Objectives of the Study}

The aim of this study is to analyse the relationship that exist between risk management techniques and insurance buying behaviour among SMEs operators. The specific objectives are to assess the effect of risk identification techniques on insurance buying behaviour of SMEs in Lagos State, Nigeria; evaluate the influence of risk assessment techniques on insurance buying behaviour of SMEs in Lagos State, Nigeria; and investigate the relationship between risk control techniques and insurance buying behaviour of SMEs in Lagos State, Nigeria. 


\section{Literature Review}

\section{Business Risk Management: Conceptual Clarifications}

Chuthamas, Aminul, Thiyada, and Dayang (2011) define a business as a controlled mechanism comprising of a detector, a selector, and an effector. Neneh and Van Zyl (2012) expressed that the sustenance of business practices is hinged upon the expression of quality managerial precepts and techniques in managing enterprises which will steadily develop business performance especially in the applicability of business excellence in core facets of a business. According to Dafikpaku (2011), business risk is depicted as the entirety of all main aspects of risks that an enterprise faces in the process of carrying out its activities. An earlier work of Olsson (2002) sees it as the peril of failing to achieve required enterprise targets as a consequence upon inappropriate tactics, restricted resources, or competitive/economic environmental changes. Dickinson (2001) as cited in Obalola and Ajemunigbohun (2017) see nosiness risks as the extent to which the consequential effects of business' corporate strategy deviate from those highlighted in its organizational missions.

However, risk as a construct is defined as anything that may cause an organisation to lose value (Turner, 2010). It is thus seen as anything that can heavily impact enterprise objectives and possibility that both desired and unanticipated circumstances may have indirect consequence on business capital and earnings (Gwangwava, Manuere, Kudakweshe, Tough, \& Rangarirai, 2014). It is described as a continuous process that can help operations, priorities, and resources, ascertain legal compliance, gaining performance targets, enhance fiduciary stability and largely avoid loss and destruction to the enterprise (Pradana \& Bandula, 2012). Kleffner, Lee, and McGannon (2003) as cited in Obalola and Ajemunigbohun (2017) stated that business risk management is the management of operational and financial risk management chronologically in order to minimise the cost appropriateness of controlling risks within the limits of business tolerance for risk. Studies (such as Gates, Nicolas, \& Walker, 2012; Gatzert\& Martin, 2013; Hoyt \& Liebenberg, 2011; Pagach \& Warr, 2010) came up that business risk management aggregate an all-round business risk by taking cognisance of interdependence between risks that permit for improved assessment of an entity's risk event and afterward increasingly link decision process with strategic and operative advancement.

\section{SMEs Risk Management}

Neneh and Van Zyl (2012) stipulated that the practices of controlling risk are a combination of diversification, recruitment, training, policy advancement, safety consciousness, cash reserve maintenance, purchasing insurance and directional termination process. Abotsi, Dake, and Agyepong (2014) opined that the ability of managers of SMEs to address the dynamics of the emerging market is substantially influenced by their ability to cautiously identify and assess the types of risks their enterprise encounters and then to evaluate the core mechanisms to controlling them. Janney and Dess (2006) as cited in Obalola and Ajemunigbohun (2017) mentioned that SMEs are not conscious of adopting positive technique towards risk management due to a number of difficulties such as inadequate infrastructure, deficiency in financial and intellectual resources, restricted managerial and technical skills, weak information systems, and inadequate amount invested in research.

Dupre (2009) came up with an allusion that owners-managers of SMEs in South Africa are substantially oblivious of the kind of business to operate and also unaware of risks that confront their businesses. He stated further that very scanty SME owner-managers are risk averse and thus put 
forward risk-related efforts to 'loss control' methods concerning fire, health, security, and quality assurance. Rao and Marie (2007) had argued that the mismanagement of risks can cause financial loss, reputational loss, reduced shareholder value and destruction of the whole business. Abotsi, Dake, and Agyepong (2014) stated that SME operators face both internal and external risks in their business, which threaten their profitability, performance and survival. Among the external risks encountered include disaster, political risks, war, civil commotions, and government policies; while internal risks include risk to compete in the marketplace, high labour injury, risk of reduced demand for goods and services, and risks to financial growth.

\section{Insurance Buying Behaviour}

The acceptance of an insurance service encourages its buying behaviour. Therefore, the basic buying behaviour for insurance arises from the utility that a consumer gains from the increase in financial security achieved by transferring the risk of loss to an insurer. Quite a number of empirical studies (such as Ajemunigbohun\& Adeoye, 2018; Meko, Lemie, \& Worku, 2018; Waheed \& Ullah, 2017) have shown that the level of insurance acceptance can be influenced by a great number of variables such as political, economic, legal and social factors. In the work of Adeleke, Olowokudejo, and Ajemunigbohun (2016), several factors noted as affecting insurance awareness and are said to include trust, publicity, dread of risk, and choice of insurance products.

Similarly, the decision to purchase not only the apparent current condition of the product, but also its future condition is encapsulated in insurance demand (Adeleke et al., 2016). Therefore, an earlier work by Beenstock, Dickson, and Khajurian (1998) mentioned that the consumer widens its economic scope of discretion and opportunity by protecting themselves from financial loss in the event of accident, fire or theft. According to several studies (such as Hagos, Kebede \&Shewakena, 2019; Krummaker, 2019; Obi, Okoronkwo, Iloh, Nwonwu, Ogbu, \& Yakubu, 2020), factors affecting the demand for insurance are said to include attitude to risk and risk awareness, the insurance price, income and wealth, risk tolerance, insurance regulation, probability of loss, and an individual degree to risk aversion. An earlier study by Rossi and Black (2001) asserted that the demand for insurance make provisions for adequate coverage in terms of loss that decreases the probability of financial crisis when risk crystallises. 


\section{ConcpetualFramwork}

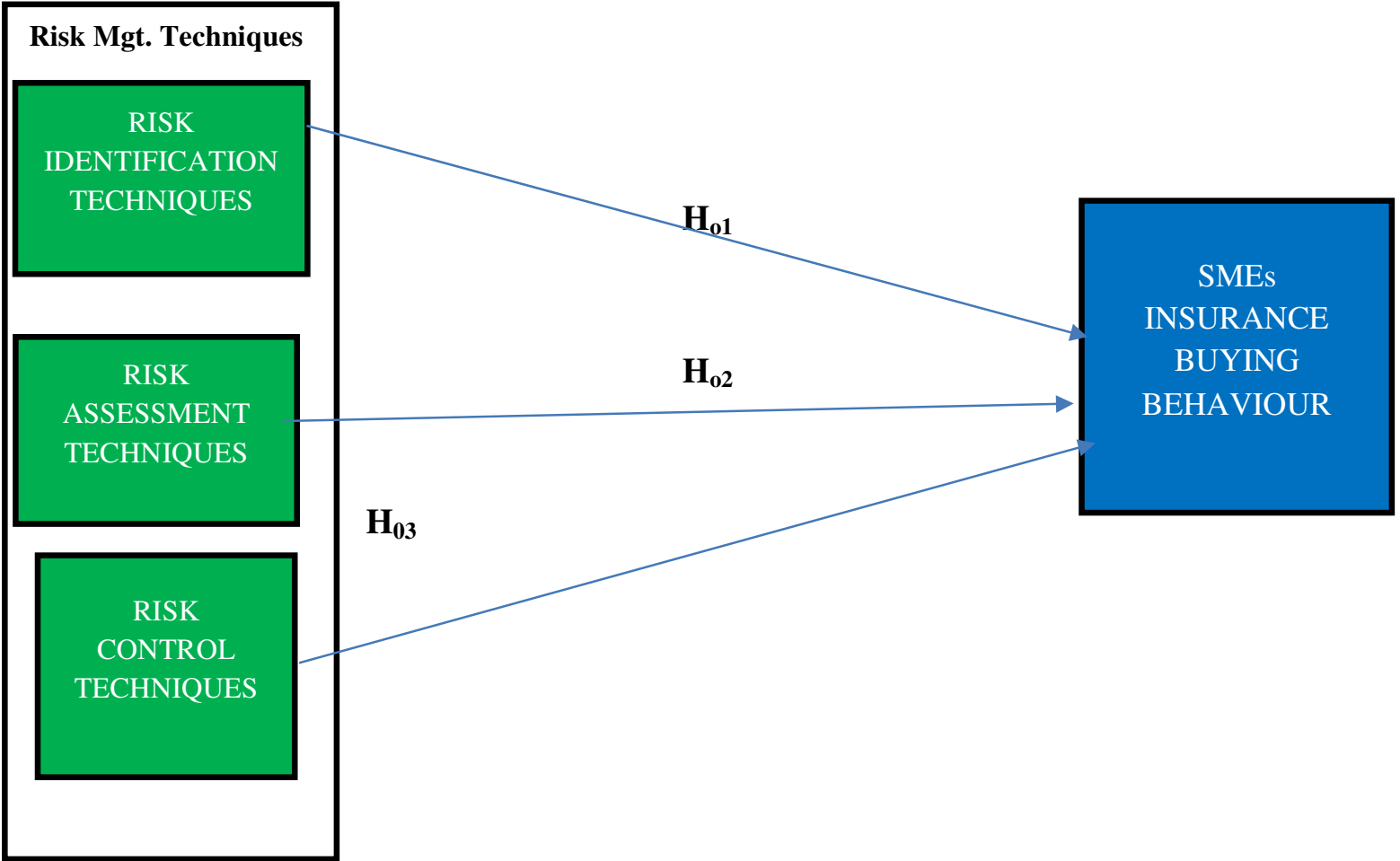

Figure 2.1Conceptual framework showing the relationship between risk management techniques and SMEs insurance buying behaviour

Source: Developed by the Researchers (2021)

\section{Theoretical Review}

The Rational Choice theory presumes that if an individual consumer is accurately informed about his needs, the maximisation of his utility is a function of the number of goods consumed, given relative prices, his income, and desires. However, changes in individual income relative to prices influence the amount of a given commodity a rational consumer will buy (Clarke, 2016). The proponents of this theory are of the view that individuals are driven by their desires or aspirations that define what they prefer. Under certain constraints and limitations which make it impossible to get all they desire; individuals will have to make choices regarding their goals and the resources for attaining them.

This theory holds that economic agents anticipate the outcomes of all possible alternatives and choose the one with the greatest potential (Scott, 2000). This theory assumes that insurance buyers are risk averse in that, first, if the cost of insurance is less than the actuarially determined value, rational people will be moved to buy insurance, and second, a rational consumer will likely not buy insurance if he is not sure that the claim, he will receive in the event of loss is greater than the cost of insurance (Kunreuther\& Pauly, 2005). This implies that as premiums decrease, there exists an expectation of an increase in demand for insurance (Du, Feng, \& Hennessy, 2014). At the same time, 
where an individual has less confidence in the insurers' entire buying process, or where he perceives that he will not be able to get fair treatment in the insurers' buying process, his behavioural attitude to insurable risk is likely to change. However, due to uncertainty concerning the future, insurance choices are not usually made based on utility alone but on a consideration of the behavioural pattern of an individual agent (Richter, Schiller, \& Schlesinger, 2014).

\section{Research Methods}

This study employed a survey research design anchored on a quantitative method to give an improved view of critical decisions connecting the nexus between risk management techniques and buying behaviour of insurance products among SMEs' operators/owners. This design thus assisted in planning and executing the research in a manner to acquire planned outcomes and thus, created a nexus with the real-life global situation (Creswell \& Creswell, 2018; Gray, 2017). Data collection was carried out through field survey among chosen small and medium-sized enterprises with the assistance of the questionnaire. The choice of selecting the participants were due to their vital significance in economic sustenance of our nation. The use of this data collection instrument was because of its appropriateness to the design of the study with regards to being relatively cheap, wider usage and more sample representative, sufficiency of time for participants to assign well thought out responses and simplicity in the administration the research instrument (Cooper \& Schindler, 2014; Kothari \& Garg, 2016).

In accordance with the Small and Medium Enterprises Development Agency of Nigeria (2013), the totality of micro, small and medium enterprises (MSMEs) as cited in Peter, Adegbuyi, Olokundun, Peter, Amaihian, and Ibinunmi (2018) stood at 37,067,416 with 36, 914,578 micro, 68,168 small and 4,670 medium enterprises. In Lagos State, the research ground, is said to have a share of 11,666 registered SMEs. 10 local government council areas out of the 20 acknowledged and approved local government councils were selected as research study areas with the adoption of single-stage cluster sampling technique. The aim of selecting this sampling technique was due to the fact that it allowed the researchers to divide the population into favourable clusters by indiscriminately selecting the needed number of clusters as representativevariables and examined all the cases in each of the randomly chosen clusters. This sampling technique is beneficial because its timely and inexpensive (Wilson, 2014).

The survey technique was segregated into two; which made up of section A and B. For section A, details of the participants were affirmed, while section B is planned in relation to the constructs in the study. The study observed tests of validity comprised of congruent, content, and criterion-related in nature. While the congruent validity was structured in accordance to preceding literature, content validity took cognisance of the specifics on the survey instrument, and the criterion-relation validity took a probe of the outcomes from other related participants (Booth, Colomb, Williams, Bizup, \& Fitzgerald, 2016). Also, the reliability test was conducted with a Cronbach alpha of 0.703, 0.814, 0.727 for risk identification techniques, risk assessment techniques, risk control techniques, and 0.713 for insurance buying behaviour. These results were in consonance with statistical interferences of the soundness of the scale, and the safety of the internal consistency. 
Since the target population comprised of all registered SMEs in Lagos metropolis, the total sample size for the study was statistically determined by Yamane's (1967) formula as cited in Ajay and Masuku (2014), given as:

$$
n=\frac{N}{1+N e^{2}}
$$

$$
n=\frac{11,666}{1+11,666(0.05)^{2}}=386
$$

In assessing the above calculated sample size, the researchers considered as representatives as possible compared to the total population under study. Data gathering period was between September, 2020 to December, 2020. Most importantly, 243 copies out of the 386 copies of questionnaire assigned to selected SMEs operators/owners were found relevant for assessment of the research outcomes; providing $63 \%$ response rate. In bid to measure gathered data successfully, simple regression technique was employed. Accordingly, Five Likert scaling measurements of 'strongly agree' 'agree', 'indifferent', 'disagree', and 'strongly disagree' were adopted

\section{Result and Discussion}

While the statistical analysis allows for a quantitative description and explanation of data collected, the descriptive analysis involves conceptual description of available data. The statistical tools employed to analyse the data are simple frequency percentage supported with verbal interpretation of results, and simple regression techniques for each hypothetical proposition.

\section{Descriptive Analysis of Risk Management Techniques \\ Business Risk Identification Techniques}

In Table 4.1.1, the business risk identification items for which data was sought from the entire respondents were brainstorming, flowchart, expert judgment, risk survey, cause and effect diagram, documentation review, industry-knowledge based experience, historical information, root cause analysis, and checklists. The respondents responded to the various items, wherein 82 percent expressed their agreement in terms of brainstorming, 16 percent indifferent, and 12 percent flaunted their disagreement. For flowchart, while respondents expressed 82.7 percent in support, 2.9 percent were in disagreement with it, then, only 14.4 percent were indecisive. As for the expert judgment,77.0 percent of the entire respondents displayed their agreement, 14.0 percent were indecisive, and 9.9 percent disagreed. For the risk survey instrument (questionnaire), 69.1 percent agreed, 21.8 percent undecided, and 9.1 percent expressed their displeasure.

For the cause-and-effect diagram, 60.9 percent agreed, 16.9 percent disagreed, and 22.2 percent were indifferent. For the documentation review, while respondents expressed 66.3 percent in support, 14.4 percent were in disagreement with it, then, only 19.3 percent were indecisive. As for the industryknowledge based experience,69.2 percent of the entire respondents displayed their agreement, 15.6 percent were indecisive, and 15.2 percent disagreed. For the historical information, 64.2 percent agreed, 21.0 percent undecided, and 14.8 percent expressed their displeasure. For the root cause analysis, 68.7 percent agreed, 13.9 percent disagreed, and 17.3 percent were indifferent. For the checklists, 78.6 percent agreed, 0.8 percent disagreed, and 20.6 percent were indifferent. The mean 
and standard deviation scores support the results. This shows that respondents' opinions to the survey items were normally distributed and centered around the mean. The result of the descriptive statistics on business risk identification techniques clearly show that all the respondents have similar opinions about all the subject matters as there are no notable differences in the distribution of the respondents' opinions.

Table 4.1.1:

Business Risk Identification Techniques

\begin{tabular}{|c|c|c|c|c|c|c|c|}
\hline \multirow{3}{*}{ Variables } & \multicolumn{5}{|c|}{ Scale Level } & \multirow{3}{*}{ Mean } & \multirow{3}{*}{ Std Dev. } \\
\hline & SD & D & $\mathbf{U}$ & $\mathbf{A}$ & $\mathbf{S A}$ & & \\
\hline & 1 & 2 & 3 & 4 & 5 & & \\
\hline $\begin{array}{l}\text { Group approach is frequently adopted technique } \\
\text { among strategic unit's heads in properly } \\
\text { identifying risk spots in my organisation }\end{array}$ & 5.8 & 6.2 & 1616.0 & 63.4 & 8.6 & 3.63 & .937 \\
\hline $\begin{array}{l}\text { My organisation uses diagrammatical lay down } \\
\text { structure in our risk identification process }\end{array}$ & 00 & 2.9 & 14.4 & 47.3 & 35.4 & 4.15 & .770 \\
\hline $\begin{array}{l}\text { Interview sections are usually granted among } \\
\text { experts in our risk identification procedures }\end{array}$ & 00 & 9.9 . & 14.0 & 37.0 & 39.1 & 4.05 & .963 \\
\hline $\begin{array}{l}\text { Risk survey/questionnaire is often designed in } \\
\text { our quest for identifying risk elements within } \\
\text { my organisation }\end{array}$ & 2.1 . & 7.0 & 21.8 & 35.4 & 33.7 & 3.92 & 1.009 \\
\hline $\begin{array}{l}\text { There is an existing diagrammatical structure for } \\
\text { identifying causes and possible effects of risks } \\
\text { in my organisation }\end{array}$ & 7.0 & 9.9 . & 22.2 & 23.5 & 37.4 & 3.74 & 1.250 \\
\hline $\begin{array}{l}\text { My organisation often engaged in } \\
\text { documentation review of possible identified risk }\end{array}$ & 2.1 & 12.3 & 19.3 & 42.0 & 24.3 & 3.74 & 1.026 \\
\hline $\begin{array}{l}\text { Industry-knowledge based experience is always } \\
\text { among techniques which informs our decision to } \\
\text { properly identifying possible risk areas in my } \\
\text { organisation }\end{array}$ & 11.1 & 4.1 & 15.6 & 35.0 & 34.2 & 3.77 & 1.271 \\
\hline $\begin{array}{l}\text { My organisation takes historical information of } \\
\text { possible identified risks in the line of our } \\
\text { operational activities }\end{array}$ & 3.7 & 11.1 & 21.0 & 35.0 & 29.2 & 3.75 & 1.105 \\
\hline $\begin{array}{l}\text { Root cause analysis is often carried out in } \\
\text { respect of possible risk occurrence in the course } \\
\text { of our organisation activities }\end{array}$ & 5.3 & 8.6 & 17.3 & 40.7 & 28.0 & 3.77 & 1.111 \\
\hline $\begin{array}{l}\text { My organisation has an existing risk checklist to } \\
\text { possibly identify any risk occurrence relating to }\end{array}$ & 0.8 & 00 & 20.6 & 46.5 & 32.1 & 4.09 & .771 \\
\hline
\end{tabular}


our operational activities

Source: Field Survey, 2021

\section{Business Risk Assessment Techniques}

In Table 4.1.2, the business risk assessment items for which data was sought from the entire respondents were changes in legislative standards, decline in the purchasing power, exchange rate fluctuations, changing lifestyles, increase in the purchase prices, loss of suppliers, the location of the store to the buyer, information gathering systems, staffing, and organisation structure and design. The respondents responded to the various items, wherein 54.7 percent expressed their low levelagreementin terms of changes in legislative standards, and 45.3 percent flaunted their moderate level of agreement. For decline in the purchasing power, while respondents expressed 30.5 percent in low level support, 69.5 percent were in moderately in agreement with it. As for the exchange rate fluctuations, while 56.8 percent of the entire respondents displayed their low-level agreement, 42 percent expressed their moderate support, and 1.2 percent showed their high-level support. For the changing lifestyles, while 57.6 percent indicated their low-level agreement, 41.2 expressed their moderate support, and 1.2 percent expressed their high-level agreement. For the increase in the purchase prices, while 45.7 percent agreed in low capacity, 54.3 percent agreed in moderate capacity. For the loss of suppliers, while respondents expressed 49.4 percent support in low level, then, 50.6 percent were moderately in support of it. As for the location of the store to the buyer, 64.6 percent of the entire respondents displayed their agreement in low capacity, and only 35.4 percent agreed moderately. For the information gathering systems, while 64.2 percent moderately agreed, 35.8 percent expressed their low agreement. For staffing, while 65 percent displayed their low-level agreement, 35 percent were for those in moderate capacity. For the organisation structure and design, while 58 percent agreed in moderate capacity, 42 percent were of low-level agreement. The mean and standard deviation scores support the results. This shows that respondents' opinions to the survey items were normally distributed and centered around the mean. The result of the descriptive statistics on business risk assessment techniques clearly show that all the respondents have similar opinions about all the subject matters as there are no notable differences in the distribution of the respondents' opinions. 
Table 4.1.2:

Business Risk Assessment Techniques

\begin{tabular}{|c|c|c|c|c|c|}
\hline \multirow{3}{*}{ Variables } & \multicolumn{5}{|c|}{ Scale Level } \\
\hline & \multirow{2}{*}{$\begin{array}{ll}\mathbf{L} \\
\mathbf{1}\end{array}$} & \multirow{2}{*}{$\begin{array}{l} \\
2\end{array}$} & \multirow{2}{*}{$\begin{array}{l}\mathbf{H} \\
3\end{array}$} & \multirow{2}{*}{ Mean } & \multirow{2}{*}{ Std Dev. } \\
\hline & & & & & \\
\hline $\begin{array}{l}\text { Changes in legislative standards of our operational } \\
\text { activities }\end{array}$ & $\overline{55.7}$ & 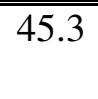 & 0.0 & 1.45 & .499 \\
\hline Decline in the purchasing power of my target population & 30.5 & 69.5 & 0.0 & 1.70 & .461 \\
\hline Exchange rate fluctuations & 56.8 & 42.0 & 1.2 & 1.46 & .569 \\
\hline Changing lifestyles -shopping tourism of the buyers & 57.6 & 41.2 & 1.2 & 1.45 & .568 \\
\hline $\begin{array}{l}\text { Increase in the purchase prices due to transportation } \\
\text { charges with small volumes of supply }\end{array}$ & 45.7 & 54.3 & 0.0 & 1.54 & .499 \\
\hline Loss of suppliers with highly standard range of products & 49.4 & 50.6 & 0.0 & 1.51 & .501 \\
\hline The location of the store to the buyer & 64.6 & 35.4 & 0.0 & 1.35 & .479 \\
\hline Information gathering systems within the organisation & 35.8 & 64.2 & 0.0 & 1.64 & .480 \\
\hline Staffing & 65.0 & 35.0 & 0.0 & 1.35 & 478 \\
\hline Organisation structure and design & 42.0 & 58.0 & 0.0 & 1.58 & .495 \\
\hline
\end{tabular}

Source: Field Survey, 2021

\section{Business Risk Control Techniques}

In Table 4.1.3, the business risk control items for which data was sought from the entire respondents were risk avoidance, risk minimisation, risk retention, and risk transfer. The respondents responded to the various items, wherein 82.4 percent expressed their agreement in terms of risk avoidance, 8.6 percent indecisive, and 9.0 percent flaunted disagreement. For the risk minimization, while respondents expressed 78.6 percent in support, 4.9 percent were in disagreement with it. Then, 16.5 were indifferent. As for the risk retention, while 70.8 percent of the entire respondents displayed their agreement, 22.2 percent expressed their indecision, and 7.0 percent showed their displeasure. For the risk transfer, while 85.3 percent agreed, 8.2 percent indecisive, and 6.5 percent disagreed. The mean and standard deviation scores support the results. This shows that respondents' opinions to the survey items were normally distributed and centered around the mean. The result of the descriptive statistics on business risk control techniques clearly show that all the respondents have similar opinions about all the subject matters as there are no notable differences in the distribution of the respondents' opinions. 


\begin{tabular}{|c|c|c|c|c|c|c|c|}
\hline \multirow{3}{*}{ Variables } & \multicolumn{5}{|c|}{ Scale Level } & \multirow{3}{*}{ Mean } & \multirow{3}{*}{ Std Dev. } \\
\hline & SD & D & $\mathbf{U}$ & $\mathbf{A}$ & SA & & \\
\hline & 1 & 2 & 3 & 4 & 5 & & \\
\hline $\begin{array}{l}\text { My organisation makes provision for physical } \\
\text { avoidance of risk occurrence in the line of } \\
\text { operations such as identifying danger zone, risk } \\
\text { communication in the workplace, etc.... }\end{array}$ & 4.9 & 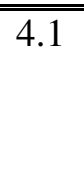 & 8.6 & 72.9 & 9.5 & 3.78 & .862 \\
\hline $\begin{array}{l}\text { My organisation often strives to reduce or } \\
\text { minimise possible risk elements for organisation } \\
\text { best interest such as provisions of fire } \\
\text { extinguisher, fire alarm, danger exit way, etc... }\end{array}$ & 0.8 & 4.1 & 16.5 & 44.0 & 34.6 & 4.07 & .864 \\
\hline $\begin{array}{l}\text { Certain risk elements not beyond the control of my } \\
\text { organisation are usually retained for possible } \\
\text { solutions such as set aside funds, hedging, minor } \\
\text { risk events, etc...... }\end{array}$ & 4.1 & 2.9 & 22.2 & 39.9 & 30.9 & 3.91 & 1.006 \\
\hline $\begin{array}{l}\text { Certain risk elements beyond the control of my } \\
\text { organisation are usually transferred to insurance } \\
\text { companies for possible solutions such as buying } \\
\text { insurance policies for business interruption } \\
\text { purpose, fire incidences, goods transportation } \\
\text { safety, staff safety etc.... }\end{array}$ & 1.6 & 4.9 & 8.2 & 42.4 & 42.8 & 4.20 & .906 \\
\hline
\end{tabular}

\section{SMEs' Insurance Buying Behaviour}

In Table 4.1.4, the SMEs' insurance buying behvaiour items for which data was sought from the entire respondents were insurance need recognition, meeting insured needs, insurance information search, insurance purchase, and insurance repeat purchase. The respondents responded to the various items, wherein 61.7 percent expressed their agreement in terms of insurance need recognition, 27.6 percent indecisive, and 10.7 percent flaunted disagreement. For the meeting insurance needs, while respondents expressed 69.2 percent in support, 4.1 percent were in disagreement with it. Then, 26.7 were indifferent. As for insurance information search, while 74.8 percent of the entire respondents displayed their agreement, 17.3 percent expressed their indecision, and 7.8 percent showed their displeasure. For insurance purchase, while 69.2 percent agreed, 21.0 percent indecisive, and 9.8 percent disagreed. For insurance repeat purchase, while 80.7 percent agreed, 15.2 percent indecisive, and 4.1 percent disagreed. The mean and standard deviation scores support the results. This shows that respondents' opinions to the survey items were normally distributed and centered around the mean. The result of the descriptive statistics on SMEs' insurance buying behaviour clearly show that all the respondents have similar opinions about all the subject matters as there are no notable differences in the distribution of the respondents' opinions. 
Table 4.1.4:

SMEs' Insurance Buying Behaviour

\begin{tabular}{|c|c|c|c|c|c|c|c|}
\hline \multirow{3}{*}{ Variables } & \multicolumn{5}{|c|}{ Scale Level } & \multirow{3}{*}{ Mean } & \multirow{3}{*}{ Std Dev. } \\
\hline & SD & D & $\mathbf{U}$ & $\mathbf{A}$ & SA & & \\
\hline & 1 & 2 & 3 & 4 & 5 & & \\
\hline $\begin{array}{l}\text { My organisation's insurance need has never been } \\
\text { recognised by insurer at any given time }\end{array}$ & 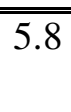 & 4.9 & 27.6 & 245.7 & 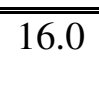 & 3.61 & 1.003 \\
\hline $\begin{array}{l}\text { My organisation's search for the necessary } \\
\text { information on my insurance policy has regularly } \\
\text { been met by my insurer }\end{array}$ & 00 & 4.1 & 26.7 & 35.0 & 34.2 & 3.99 & .881 \\
\hline $\begin{array}{l}\text { My organisation's assessment of insurance } \\
\text { products, over the years, has really been } \\
\text { significantly linked with my information search }\end{array}$ & 2.9 & 4.9 & 17.3 & 50.2 & 24.7 & 3.89 & .932 \\
\hline $\begin{array}{l}\text { My organisation's demand for insurance products } \\
\text { is based on necessary evaluation and decision of } \\
\text { where to buy and what type of insurance to buy }\end{array}$ & 2.1 & 7.8 & 21.0 & 34.5 & 35.0 & 3.92 & 1.028 \\
\hline $\begin{array}{l}\text { My organisation's demand for insurance is usually } \\
\text { increased by repeat purchase }\end{array}$ & 0.0 & 4.1 & 15.2 & 43.6 & 37.0 & 4.14 & .819 \\
\hline
\end{tabular}




\section{Hypotheses testing}

Table 4.2.1: Simple Regression Results for Risk Identification Techniques vs. Insurance Buying Behaviour

\begin{tabular}{|c|c|c|c|c|c|c|c|c|c|}
\hline \multicolumn{10}{|c|}{ Model Summary } \\
\hline \multirow{2}{*}{$\begin{array}{l}\text { M } \\
\text { od } \\
\text { el }\end{array}$} & \multirow[t]{2}{*}{$\mathrm{R}$} & \multirow[t]{2}{*}{ R Square } & \multirow{2}{*}{$\begin{array}{l}\text { Adjuste } \\
\text { d R } \\
\text { Square }\end{array}$} & \multirow{2}{*}{$\begin{array}{l}\text { Std. } \\
\text { Error of } \\
\text { the } \\
\text { Estimate }\end{array}$} & \multicolumn{5}{|c|}{ Change Statistics } \\
\hline & & & & & $\begin{array}{l}\mathrm{R} \text { Square } \\
\text { Change }\end{array}$ & $\begin{array}{l}\mathrm{F} \\
\text { Change }\end{array}$ & df1 & df2 & $\begin{array}{ll}\text { Sig. } & F \\
\text { Change } & \end{array}$ \\
\hline 1 & $.301^{\mathrm{a}}$ & .090 & .087 & 2.573 & .090 & 23.970 & 1 & 241 & .000 \\
\hline \multicolumn{10}{|c|}{ a. Predictors: (Constant), Risk identification techniques } \\
\hline \multicolumn{10}{|c|}{ ANOVA $^{\mathrm{a}}$} \\
\hline \multicolumn{3}{|c|}{ Model } & \multirow{2}{*}{\multicolumn{2}{|c|}{$\begin{array}{l}\text { Sum of Squares } \\
158.682\end{array}$}} & Df & \multirow{2}{*}{\multicolumn{2}{|c|}{\begin{tabular}{|l|} 
Mean Square \\
158.682 \\
\end{tabular}}} & $\mathrm{~F}$ & Sig. \\
\hline \multirow{3}{*}{1} & \multicolumn{2}{|c|}{ Regression } & & & 1 & & & 23.970 & $.000^{\mathrm{b}}$ \\
\hline & Residu & & \multicolumn{2}{|c|}{1595.425} & 241 & \multicolumn{2}{|c|}{6.620} & & \\
\hline & \multicolumn{2}{|c|}{ Total } & \multicolumn{2}{|c|}{1754.107} & 242 & & & & \\
\hline \multicolumn{10}{|c|}{ a. Dependent Variable: Insurance buying behaviour } \\
\hline \multicolumn{10}{|c|}{$\begin{array}{l}\text { a. Predictors: (Constant), Risk identification techniques } \\
\text { Coefficients }^{\mathbf{a}}\end{array}$} \\
\hline \multicolumn{10}{|c|}{ Coefficients $^{\mathrm{a}}$} \\
\hline \multirow{2}{*}{\multicolumn{3}{|c|}{ Model }} & \multicolumn{2}{|c|}{$\begin{array}{l}\text { Unstandardized } \\
\text { Coefficients }\end{array}$} & $\begin{array}{l}\text { Standardiz } \\
\text { ed } \\
\text { Coefficien }\end{array}$ & \multirow[t]{2}{*}{$\mathrm{T}$} & \multirow[t]{2}{*}{ Sig. } & \multicolumn{2}{|c|}{$\begin{array}{l}95.0 \% \text { Confidence } \\
\text { Interval for B }\end{array}$} \\
\hline & & & B & \begin{tabular}{|l|} 
Std. \\
Error
\end{tabular} & Beta & & & $\begin{array}{l}\text { Lower } \\
\text { Bound }\end{array}$ & $\begin{array}{l}\text { Upper } \\
\text { Bound }\end{array}$ \\
\hline \multirow[b]{2}{*}{1} & \multicolumn{2}{|c|}{ (Constant) } & 13.482 & 1.251 & & 10.780 & .000 & 11.018 & 15.946 \\
\hline & \multicolumn{2}{|c|}{$\begin{array}{l}\text { Risk identification } \\
\text { techniques }\end{array}$} & .157 & .032 & .301 & 4.896 & .000 & .094 & .220 \\
\hline
\end{tabular}

Source: Authors' computation, 2021

From the results of the regression analysis presented above, it is clear that there is positively low relationship between risk identification techniques and insurance buying behaviour. The model also shows the variations experienced by the dependent variable that could be explained by the independent variable ( $\mathrm{R}$ square) which shows that risk identification techniques are responsible for about $9 \%$ of variance in SMEs operators' insurance buying behaviour. This means that $91 \%$ of the insurance buying behaviour enjoyed by the insurers comes from other factors other than the predictor used in this model (risk identification techniques). The generalisation of the results (Adjusted $\mathrm{R}$ square) indicates that true $8.7 \%$ of the variation in insurance buying behaviour is explained by risk identification techniques. This result is almost close to reality as the difference between R Square and Adjusted R Square is not high. The standard error fit, which is a measure of the precision of the model, shows how wrong the statistical outcomes could be at $3 \%$ if one uses this model to make real life predictions. The above result is statistically significant as seen in the ANOVA table ( $\mathrm{p}$-value $=$ 0.157 ) as they are less than the 0.05 confidence interval used in this study. A value greater than 1 shows that F-ratio yield an efficient model but 23.97 F-ratio indicates that this model is not very efficient. 
Table 4.2.2: Simple Regression Results for Risk Assessment Techniques vs. Insurance Buying Behaviour

\begin{tabular}{|c|c|c|c|c|c|c|c|c|c|}
\hline \multicolumn{10}{|c|}{ Model Summary } \\
\hline \multirow{2}{*}{$\begin{array}{l}\text { M } \\
\text { od } \\
\text { el }\end{array}$} & \multirow[t]{2}{*}{\begin{tabular}{|l|l|l}
$\mathrm{R}$ &
\end{tabular}} & \multirow[t]{2}{*}{ R Square } & \multirow{2}{*}{$\begin{array}{l}\text { Adjuste } \\
\mathrm{d} \quad \mathrm{R} \\
\text { Square }\end{array}$} & \multirow{2}{*}{$\begin{array}{l}\text { Std. } \\
\text { Error of } \\
\text { the } \\
\text { Estimate }\end{array}$} & \multicolumn{5}{|c|}{ Change Statistics } \\
\hline & & & & & $\begin{array}{l}\mathrm{R} \text { Square } \\
\text { Change }\end{array}$ & $\begin{array}{l}\mathrm{F} \\
\text { Change }\end{array}$ & df1 & df2 & $\begin{array}{ll}\text { Sig. } & F \\
\text { Change } & \end{array}$ \\
\hline 1 & \begin{tabular}{|l|l}
$.260^{\mathrm{a}}$ &.
\end{tabular} & .067 & .054 & 4.205 & .067 & 17.416 & 1 & 241 & .000 \\
\hline \multirow{2}{*}{\multicolumn{10}{|c|}{ a. Predictors: (Constant), Risk assessment techniques }} \\
\hline & & & & \multicolumn{6}{|c|}{ ANOVA $^{\text {a }}$} \\
\hline \multicolumn{3}{|c|}{ Model } & \multicolumn{2}{|c|}{ Sum of Squares } & Df & \multicolumn{2}{|c|}{ Mean Square } & $\mathrm{F}$ & Sig. \\
\hline \multirow{3}{*}{1} & \multicolumn{2}{|l|}{ Regression } & \multicolumn{2}{|c|}{118.216} & 1 & \multicolumn{2}{|c|}{118.216} & 17.416 & $.000^{\mathrm{b}}$ \\
\hline & \multicolumn{2}{|l|}{ Residual } & \multicolumn{2}{|c|}{1635.891} & 241 & \multicolumn{2}{|l|}{6.788} & & \\
\hline & \multicolumn{2}{|c|}{ Total } & \multicolumn{2}{|c|}{1754.107} & 242 & & & & \\
\hline \multicolumn{10}{|c|}{ a. Dependent Variable: Insurance buying behaviour } \\
\hline \multirow{2}{*}{\multicolumn{10}{|c|}{ b. Predictors: (Constant), Risk assessment techniques }} \\
\hline & & & & & & & & & \\
\hline \multirow{2}{*}{\multicolumn{3}{|c|}{ Model }} & \multicolumn{2}{|c|}{$\begin{array}{l}\text { Unstandardized } \\
\text { Coefficients }\end{array}$} & $\begin{array}{l}\text { Standardiz } \\
\text { ed } \\
\text { Coefficien } \\
\text { ts }\end{array}$ & \multirow[t]{2}{*}{$\mathrm{T}$} & \multirow[t]{2}{*}{ Sig. } & \multicolumn{2}{|c|}{$\begin{array}{l}95.0 \% \text { Confidence } \\
\text { Interval for B }\end{array}$} \\
\hline & & & B & $\begin{array}{l}\text { Std. } \\
\text { Error }\end{array}$ & Beta & & & $\begin{array}{l}\text { Lower } \\
\text { Bound } \\
\end{array}$ & \begin{tabular}{|l|} 
Upper \\
Bound
\end{tabular} \\
\hline \multirow[b]{2}{*}{1} & \multicolumn{2}{|l|}{ (Constant) } & 13.949 & 1.353 & & 10.312 & .000 & 11.285 & 16.614 \\
\hline & $\begin{array}{l}\text { Risk } \\
\text { techniques }\end{array}$ & assessment & .373 & .089 & .260 & 4.173 & .000 & .197 & .549 \\
\hline
\end{tabular}

Source: Authors' computation, 2021

From the results of the regression analysis presented above, it is clear that there is positively low relationship between risk assessment techniques and insurance buying behaviour. The model also shows the variations experienced by the dependent variable that could be explained by the independent variable ( $\mathrm{R}$ square) which shows that risk assessment techniques are responsible for about $6.7 \%$ of variance in SMEs operators' insurance buying behaviour. This means that $93.3 \%$ of the insurance buying behaviour enjoyed by the insurers comes from other factors other than the predictor used in this model (risk assessment techniques). The generalisation of the results (Adjusted $\mathrm{R}$ square) indicates that true $5.4 \%$ of the variation in insurance buying behaviour is explained by risk assessment techniques. This result is almost close to reality as the difference between R Square and Adjusted R Square is not high. The standard error fit, which is a measure of the precision of the model, shows how wrong the statistical outcomes could be at $4 \%$ if one uses this model to make real life predictions. The above result is statistically significant as seen in the ANOVA table (p-value = 0.373 ) as they are less than the 0.05 confidence interval used in this study. A value greater than 1 shows that F-ratio yield an efficient model but 17.416 F-ratio indicates that this model is not very efficient. 
Table 4.2.3: Simple Regression Results for Risk Control Techniques vs. Insurance Buying Behaviour

\begin{tabular}{|c|c|c|c|c|c|c|c|c|c|}
\hline \multicolumn{10}{|c|}{ Model Summary } \\
\hline \multirow{2}{*}{$\begin{array}{l}\text { M } \\
\text { od } \\
\text { el }\end{array}$} & \multirow[t]{2}{*}{$\mathrm{R}$} & \multirow[t]{2}{*}{ R Square } & \multirow{2}{*}{$\begin{array}{l}\text { Adjuste } \\
\mathrm{d} \quad \mathrm{R} \\
\text { Square }\end{array}$} & \multirow{2}{*}{$\begin{array}{l}\text { Std. } \\
\text { Error of } \\
\text { the } \\
\text { Estimate }\end{array}$} & \multicolumn{5}{|c|}{ Change Statistics } \\
\hline & & & & & $\begin{array}{l}\mathrm{R} \text { Square } \\
\text { Change }\end{array}$ & $\begin{array}{l}\mathrm{F} \\
\text { Change }\end{array}$ & df1 & df2 & $\begin{array}{ll}\text { Sig. } & F \\
\text { Change } & \end{array}$ \\
\hline 1 & $.514^{\mathrm{a}}$ & .264 & .193 & 2.314 & .264 & 72.568 & 1 & 241 & .000 \\
\hline \multicolumn{10}{|c|}{ a. Predictors: (Constant), Risk identification techniques } \\
\hline \multicolumn{10}{|c|}{ ANOVA $^{\mathrm{a}}$} \\
\hline \multicolumn{3}{|c|}{ Model } & \multicolumn{2}{|c|}{ Sum of Squares } & Df & \multicolumn{2}{|c|}{ Mean Square } & $\mathrm{F}$ & Sig. \\
\hline \multirow{3}{*}{1} & \multicolumn{2}{|c|}{ Regression } & \multicolumn{2}{|c|}{463.566} & 1 & \multicolumn{2}{|c|}{463.566} & 72.568 & $.000^{\mathrm{b}}$ \\
\hline & \multicolumn{2}{|c|}{ Residual } & \multicolumn{2}{|c|}{1290.541} & 241 & \multicolumn{2}{|l|}{5.355} & & \\
\hline & \multicolumn{2}{|c|}{ Total } & \multicolumn{2}{|c|}{1754.107} & 242 & & & & \\
\hline \multicolumn{10}{|c|}{ a. Dependent Variable: Insurance buying behaviour } \\
\hline \multirow{2}{*}{\multicolumn{10}{|c|}{ c. Predictors: (Constant), Risk identification techniques }} \\
\hline & & & & & & & & & \\
\hline \multirow{2}{*}{\multicolumn{3}{|c|}{ Model }} & \multicolumn{2}{|c|}{$\begin{array}{l}\text { Unstandardized } \\
\text { Coefficients }\end{array}$} & $\begin{array}{l}\text { Standardiz } \\
\text { ed } \\
\text { Coefficien } \\
\text { ts }\end{array}$ & \multirow[t]{2}{*}{$\mathrm{T}$} & \multirow[t]{2}{*}{ Sig. } & \multicolumn{2}{|c|}{$\begin{array}{l}95.0 \% \text { Confidence } \\
\text { Interval for B }\end{array}$} \\
\hline & & & B & $\begin{array}{l}\text { Std. } \\
\text { Error }\end{array}$ & Beta & & & $\begin{array}{l}\text { Lower } \\
\text { Bound }\end{array}$ & $\begin{array}{l}\text { Upper } \\
\text { Bound }\end{array}$ \\
\hline \multirow[b]{2}{*}{1} & \multicolumn{2}{|c|}{ (Constant) } & 8.278 & 1.221 & & 6.781 & .000 & 5.873 & 10.683 \\
\hline & \multicolumn{2}{|c|}{$\begin{array}{l}\text { Risk } \\
\text { techniques }\end{array}$} & .607 & .076 & .514 & 9.304 & .000 & .557 & .856 \\
\hline
\end{tabular}

Source: Authors' computation, 2021

From the results of the regression analysis presented above, it is clear that there is positively moderate relationship between risk control techniques and insurance buying behaviour. The model also shows the variations experienced by the dependent variable that could be explained by the independent variable ( $\mathrm{R}$ square) which shows that risk control techniques are responsible for about $26.4 \%$ of variance in SMEs operators' insurance buying behaviour. This means that $73.6 \%$ of the insurance buying behaviour enjoyed by the insurers comes from other factors other than the predictor used in this model (risk control techniques). The generalisation of the results (Adjusted R square) indicates that true $19.3 \%$ of the variation in insurance buying behaviour is explained by risk control techniques. This result is almost close to reality as the difference between R Square and Adjusted R Square is not high. The standard error fit, which is a measure of the precision of the model, shows how wrong the statistical outcomes could be at $2 \%$ if one uses this model to make real life predictions. The above result is statistically significant as seen in the ANOVA table (p-value = 0.607 ) as they are less than the 0.05 confidence interval used in this study. A value greater than 1 shows that F-ratio yield an efficient model but 72.568 F-ratio indicates that this model is not very efficient. 


\section{Discussion of Findings}

From the empirical analyses and the tests of hypotheses carried out, this study confirmed the relationship between risk management techniques and insurance buying behaviour among SMEs operators/owners in Lagos State, Nigeria; with respect to the research objectives and research questions raised.

The result shows that risk identification techniques have positive and low relationship with the insurance buying behaviourof SMEs owners/operators in Lagos State, Nigeria, thereby invalidating the null hypothesis and validating the alternate hypothesis at $(\mathrm{p}=0.000)$. This result corroborates the findings of Afolabi and James (2018); Mayer (2017); Olowokudejo and Nwankwo (2016); Wang, Li, $\mathrm{Li}, \mathrm{Zhu}$, and Li (2019). Olowokudejo and Nwankwo (2016) pointed at risk identification techniques as key instruments to influencing insurance consumptions among SMEs. Jenya and Sandada (2017) considered risk identification as first risk management instrument in being able to manage business risks responsibly.

The result shows that risk assessment techniques have positively low relationship with the insurance buying behaviourof SMEs owners/operators in Lagos State, Nigeria, thereby invalidating the null hypothesis and validating the alternate hypothesis at $(\mathrm{p}=0.000)$. This result is supported with the views of Ajemunigbohun and Adeoye (2018), Grondys et al (2021); Obalola and Ajemunigbohun (2016); and Olowokudejo and Nwankwo (2016); who also derived a positive but low level of nexus between insurance buying behaviour with respect to risk assessment techniques. They justify the choices of insurance as an effective risk communication in measuring the behavioural attitudes of individual SMEs.

The result shows that risk control techniques have positively moderate relationship with the insurance buying behaviourof SMEs owners/operators in Lagos State, Nigeria, thereby invalidating the null hypothesis and validating the alternate hypothesis at $(\mathrm{p}=0.000)$. The result is supported by Obalola and Ajemunigbohun (2017) findings noting that risk control technique such as insurance can influence behavioural attitude of SMEs operators to managing risks of any kind in their respective enterprises. The studies of Dayour et al. (2020) and Chatterjee and Wehrhah (2017) pinpointed at insurance as required financial instrument to enhancing the capacities of Micro, Small and Mediumsized enterprises in

\section{Conclusion and Recommendations}

From the empirical analyses conducted and the test of hypotheses carried out, this study has been able to address the research objectives. The results show that risk management techniques have positively low and moderate effects on the insurance buying behaviour among SMEs operators/ owners in Lagos, Nigeria, leading to the rejection of all null hypotheses at 0.05 level of significance. The findings show that risk management techniques play a vital role in moderating insurance buying behaviour among SMEs owners and related industry. The responses of the respondents largely provedthat effective implementation of risk management techniques will help enhance the capacity of SMEs operators to a moderate extent. In addition, the fact that it is only an insignificant number (2\%) that would purchase insurance policies in Nigeria due to perceived insurers' claims processes is a challenge that insurers in Nigeria will have to deal with. The findings of this research reveal that 
risk management techniques are significant in influencing insurance buying behaviour among SMEs owners/operators. Thus, insurance providers in Nigeria should focus on the risk management proxies that will have greater effects on the buying behaviour of the SMEs owners/operators and other entrepreneurs or business-related industries.

Based on the justification adduced to in this study, the researchers recommended that insurance education, as a field of study, should be taken as seriously as possible so that it can help develop the peoples' minds psychologically and sociologically to get attracted to insurance in order to manage their future. More so, insurance providers in Nigeria should make attempt to make the business of insurance lovable and affordable to SMEs' operators/owners in a bid to sharpen their behavioural risk attitudes. The SMEs operators should try to shift their desire to managing the thrust of risk off to the insurance providers for adequate business, economic and financial security. Also, inordinate interest should be placed onimpressive risk management communication and ideal risk financing techniques among SMEs' owners/operators. Enlightenment programmes should be carried out among SMEs operators to enable them to be aware that risk management experts, which includes insurers, are ideal candidates to adequately assess existing risk management systems and help them to better priced their credit and other financial risk. Insurers are expected to provide special funds to financially support for uninsurable risks of the operators in a bid to enhance the value of insurance among businesses.

\section{Contributions to Knowledge and Suggestions for Future Research}

It is established in this study that there are relationships between risk management techniques and insurance buying behaviour of SMEs owners/operators. This study has been able to help in establishing a link between risk management techniques and insurance buying behaviour among SMEs in Nigeria. Despite the recommendations highlighted, the study has some limitations. First, the study's findings are viewpoints of SMEs owners/operators in Lagos State. This is just a representation of the study population, which may affect the generalisation of the entire population. This means that the generalisation of the findings should be made with caution. Given this implication, similar studies should be carried out in other industries in Nigeria.

It is being suggested that further research works should focus attention on behavioural attitudes of policyholders in Nigeria. Research work is thus encouraged to look at behavioural factors that can influence more preferences for insurance products in Nigeria. Lastly, future research work could direct attention at sociology and psychology of insurance.

\section{Acknowledgement}

This article is sponsored by Tertiary Education Trust Fund (TETFUND), Nigeria.

\section{References}

Abotsi, A.K., Dake, G.Y., and Agyepong, R.A. (2014). Factors influencing risk management decision of small and medium scale enterprise in Ghana. Ghana: Vizja Press \& IT.I

Adeleke, I., Olowokudejo, F., and Ajemunigbohun, S. (2016). Hazard perception and demand for insurance among selected motorcyclists in Lagos, Nigeria. The South East Asian Journal of Management, 10 (2), 121-140. 
Adeyele, J.S., and Osemene, O.F. (2018). Small and medium enterprises' risk exposure and mitigation approaches in Nigeria. The Journal of Entrepreneurial Finance, 20 (1), 21-42.

Afolabi, T.S. and James, J.T. (2018). Risk management and performance of small and medium enterprises in Osun State, Nigeria. Archives of Business Research, 6 (12), 157-163.

Ajay, S., and Masuku, M.B. (2014). Sampling techniques and determination of sample size in applied statistics research: An overview. International Journal of Economics, Commerce, and Management, 2 (1), 1-22.

Ajemunigbohun, S.S., and Adeoye, A.O. (2018). Insurance awareness and acceptance: Empirical evidence among small and medium-sized enterprises in Lagos State, Nigeria. Trends Economics and Management, 32 (2), 9-20.

Ajemunigbohun, S.S., Isimoya, O.A., and Elegunde, A.F. (2020). Risk attitude, insurance patronage, and SMEs performance: Empirical evidence from Lagos, Nigeria. Annals of 'Dunarea de Jos' University of Galati, 26 (2), 70-78.

Al-Qubtan, T.R., Gan, P., Abd. Hadi, F.S., Abdul Jalil, N., and Rambeli, N. (2021). Practical risk management approaches among small and medium enterprises. TEM Journal, 10 (2), 9961004.

Ayyagari, M., Demirguc-Kunt, A., and Maksimovic, V. (2011). Small vs. young firm across the World: Contribution to employment, job creation and growth. Policy Research. Working Paper, 5631, World Bank: Washington, DC.

Beenstock, M., Dickson, G., and Khajurian, S. (1988). The relationship between property-liability insurance premiums and income: An international analysis. Journal of Risk and Insurance, 55 (2), 259-272.

Booth, W.C., Colomb, G.G., Williams, J.M., Bizup, J., and Fitzgerald, W.T. (2016). The craft of research. $4^{\text {th }} \mathrm{ed}$. Chicago: The University of Chicago Press.

Chatterjee, A., and Wehrhahn, R. (2017, April). Insurance for micro, small and medium-sized enterprise. No. 78. ADR Brief.

Chodokufa, K. (2016). Risk management practices and the purchase of insurance by SMEs. Risk Governance \& Control: Financial Markets \& Institutions, 6 (3), 100-104.

Chodokufa, K., and Chiliya, N. (2014). The relationship between SMEs and insurance providers in Nelson Mandela Metropolitan Area, South Africa. Mediterranean Journal of Social Science, 5 (14), 84-96.

Chuthamas, C., Aminul, I., Thiyada, K., and Dayang, H.Y. (2011). Factors affecting business success of small and medium enterprise (SMEs) in Thailand. Asian Social Science, 7 (5), 180-190.

Clarke, D.J. (2016). A theory of rational demand for index insurance. American Economic Journal: Microeconomics, 8 (1), 283-306. 
Cooper, D.R. and Schindler, P.S. (2014). Business research methods. $12^{\text {th }}$ ed. New York: McGrawHill Irwin.

Creswell, J.W. and Creswell, D.J. (2018). Research design: Qualitative, quantitative, and mixed methods approach. $5^{\text {th }}$ ed. New Delhi: Sage Publications India Pvt Limited.

Dafikpaku, E. (2011). The strategic implications of enterprise risk management: A framework. ERM Symposium.

Dayour, F., Adongo, C.A., and Kimbu, A.N. (2020). Insurance uptake among small and mediumsized tourism and hospitality enterprises in a resource-scarce environment. Tourism Management Perspective, 34,1-13.

Du, X., Feng, H., and Hennessy, D.A. (2014). Rationality of choices in subsidised crop insurance markets. American Journal of Agricultural Economics, 99 (3), 732-756.

Dupre, A (2009). Linking risk management to the budgeting process. CMA Management, August/September, 17-18.

Ekwere, N. (2016). Framework of effective risk management in small and medium enterprise (SMEs): A literature review. Nomor, 1, 23-46.

Gates, S., Nicolas, J., and Walker, P.L. (2012). Enterprise risk management: A process for enhanced management and improved performance. Management Accounting Quarterly, 13 (3), 28- 38.

Gatzert, N., and Martin, M. (2013). Determinants and value of enterprise risk management: Empirical evidence from the literature, Working Paper, Friedrich-Alexander University (FAU), Erlangen-Numberg.

Gray, D.E. (2017). Doing research in the business world. New Delhi: Sage Publications AsiaPacific Pte Limited.

Grondys, K., Slusarczyk, O., Hussain, H.I., and Androniceanu, A. (2021). Risk assessment of the SME sector operations during the Covid-19 pandemic. International Journal of Environmental Research and Public Health, 18, 1-19.

Gwangwava, E., Manuere, F., Kudakwashe, G., Tough, C., and Rangarirai, F. (2014). An assessment of risk management practices in SMEs in Zimbabwe: A review and synthesis. IOSA Journal of Humanities and Social Science, 19 (8), 6-14.

Hagos, H.A., Kebede, E.Y., and Shewakena, B. (2019). Demand for life insurance and its determinants at household level: Evidence from Dire Dawa City. Research Journal of Finance and Accounting, 10 (17), 51-66.

Hoyt, R.E., and Liebenberg, A.P. (2011). The value of enterprise risk management. Journal of Risk and Insurance, 78 (4), 795-822. 
Ibiwoye, A., Mojekwu, J., and Dansu, F. (2020). Enterprise risk management practices and survival of small and medium scale enterprises in Nigeria. Studies in Business and Economics, 15 (1), 68-82.

Jenya, B., and Sandada, M. (2017). Enhancing success of SMEs through risk enterprise management: Evidence from a developing country. Pakistan Journal of Applied Economics, 27 (2), 173-188.

Kehinde, A., Opeyemi, A., Benjamin, A., Adebayo, O., and Abel, O.A. (2017). Enterprise risk management and the survival of small business in Nigeria. International Journal of Accounting Research, 5 (12), 1-8.

Kothari, C. and Garg, G. (2016). Research methodology: Methods and techniques. $3^{\text {rd }}$ ed. New Delhi: New Age International (P) Limited.

Krummaker, S. (2019). Firm's demand for insurance: An explorative approach. The American Risk and Insurance Association, 22, 279-301.

Kunreuther, H., and Pauly, M. (2005). Insurance decision-making and market behavior. Foundation and Trends in Microeconomics, 1(2), 63-127.

Ledwin, C., and Watson, M. (2019). Risk attitude, risk perception, and risk management strategies adoption in Zimbabwean small and medium enterprises. Journal of Management and Economic Studies, 1 (2), 53-68.

Lima, P.F., andVerbano, C. (2019). Project risk management implementation in SMEs: A case study from Italy. Journal of Technology, Management, and Innovation, 14 (1), 3-10.

Mayer, H. (2017). Political risk insurance and its effectiveness in supporting private sector investment in fragile states. UK: University of Oxford.

Meko, M., Lemie, K., and Worku, A. (2018). Determinants of Life insurance demand in Ethiopia. Journal of Economics, Business, and Accountancy Ventura, 21 (3), 293-301.

Mensah, S. (2004). A review of SMEs financing schemes. UNIDO Regional Workshop of Financing Small and Medium Scale Enterprise.

Neneh, N.B., and Van Zly, J.H. (2012). Achieving optimal business performance through business practices: Evidence from SMEs in selected areas in South Africa. Southern African Business Review, 16 (3), 118-144.

Obalola, M.A., and Ajemunigbohun, S.S. (2017). An analytical study of business risk management among selected small and medium enterprises in Lagos State, Nigeria. LASU Journal of Business Review, 4 (1), 35-46.

Obi, I.V., Okoronkwo, I.L., Iloh, G.U.P., Nwonwu, E.U., Ogbu, K., and Yakubu, A.A. (2020). Critical determinants of demand for services in the Nigeria formal sector social health insurance programme. International Journal of Health Economics and Policy, 5 (1), 1-8. 
Olowokudejo, F.F., and Nwankwo, S.I. (2016). Business risk management and organizational performance: Empirical evidence from small and medium enterprise (SMEs) in Nigeria. Economics and Management, 1, 32-41.

Olsson, C. (2002). Risk Management in emerging markets: How to survive and prosper. Great Britain: Pearson Education Limited.

Pagach, D., and Warr, R. (2010). The effects of enterprise risk management on firm performance, Working Paper, North Carolina State University, Raleigh.

Peter, F.O., Adegbuyi, O., Olokundun, M.A., Peter, A.O., Amaihian, A.B., and Ibidunmi, S.A. (2018). Government support and financial performance of SMEs. Academy of Strategic Management Journal, 17 (3), 1-10.

Pradana, M., and Bandula, J. (2012). Risk management practices in small and medium enterprise: Evidence from Sri Lanka. International Journal of Multidisciplinary Research, 2 (7), 226234.

Rao, A., and Marie, A. (2007). Current practices of enterprise risk management in Dubai. Management Accounting Quarterly, 8 (3), 10-22.

Richter, A., Schiller, J., and Schlesinger, H. (2014). Behavioural insurance: Theory and experiments, Journal of Risk and Uncertainty, 48, 85-96.

Scott, J. (2000). Rational choice theory. In G. Browning, A. Halcli, and F. Webster (Eds.), Understanding contemporary society: Theories of the present (pp. 126-138). London: Sage Publications.

Turner, J.S. (2010). Business risk and the tradeoff theory of capital structure: Predicting the use of term debt in the healthcare sector. A dissertation submitted in partial fulfillment of Doctor of Philosophy. University of Michigan.

Waheed, A., and Ullah, K.S. (2017). Determinants of Takaful and conventional insurance demand: A regional analysis. Cogent Economics and Finance, 5 (1), 1-18.

Wang, Y., Li, B., Li, G., Zhu, X., and Li, J. (2019). Risk factors identification and evolution analysis from textual risk disclosures for insurance industry. Procedia Computer Science, 162, 25-32.

Wilson, J. (2014). Essential of business research: A guide to doing your research project. 2nd ed. London: Sage Publication Limited.

Zoghi, F.S. (2017). Risk management practice and SMEs: An empirical study on Turkish SMEs. International Journal of Trade, Economics and Finance, 8 (2), 123-127. 